\title{
Impact of using lightweight eco-bricks as enclosures for individual houses of one story on zones of high seismicity.
}

\author{
D. Dominguez ${ }^{a}$; V. P. Muñoz. ${ }^{b} \bowtie ;$ V. L. Muñoz \\ a) Facultad de Ingeniería. Universidad Talca de Chile (Facultad de Ingeniería de Construcción), Curicó, (Maule, Chile) \\ b) Facultad de Ingeniería. Universidad Autónoma de Chile, Talca, (Maule, Chile) \\ c) Universidad Internacional de La Rioja, Logroño, (La Rioja, Spain) \\ \pmunozv@uautonoma.cl
}

\author{
Received 1 March 2016 \\ Accepted 27 October 2016 \\ Available on line 22 September 2017
}

\begin{abstract}
Fired clay bricks are widely developed by focusing on the use of several wastes with the aim of obtaining lightweight materials. Despite research having provided positives experiences, most of these showed an important reduction of compression strength. This issue must be highlighted in particular, when seismic areas are considered. However, despite compression strength decreases in some cases the energy that can be absorbed by the brick might be increased. Hence, this paper tests and shows physical and mechanical properties of newly fired clays made by adding different percentages of sawdust. Results are used for calculating the response of an individual one-story house to medium intensity earthquakes. It is concluded that the use of bricks, with up to $5 \%$ sawdust added, is an ecological way for recycling these agro-wastes, while its behaviour against earthquakes performs better than other solutions, such as common perforated bricks.
\end{abstract}

KEYWORDS: Fired Clay Brick; Organic Admixture; Mechanical properties; Earthquake; Modelization; Method of finite elements

Citation/Citar como: Domínguez, D.; Muñoz, V.P.; Muñoz, V.L. (2017) Impact of using lightweight eco-bricks as enclosures for individual houses of one story on zones of high seismicity. Mater. Construcc. 67 [328], e133. http:// dx.doi.org/10.3989/mc.2017.03316

RESUMEN: Impacto de la utilización de eco-ladrillos, como envolventes para viviendas unifamiliares de una planta, en zonas de alta sismicidad. Los ladrillos de arcilla cocida, fabricados con ciertos residuos, a fin de aligerarlos, es una alternativa ampliamente desarrollada. A pesar de que han dado resultados positivos, la mayor parte han mostrado una importante reducción de la resistencia mecánica. Este problema, es especialmente relevante cuando se considera su uso en zonas sísmicas. Sin embargo, a pesar de que la resistencia a la compresión disminuye, en algunos casos, la energía que puede absorber aumenta. De este modo, el artículo ensaya y muestra las propiedades físicas y mecánicas de la arcilla cocida, fabricada añadiendo serrín de madera. Los resultados obtenidos han servido para calcular la respuesta ante un sismo de intensidad media para un modelo de edificio de una planta. Se ha concluido que el uso de ladrillos fabricados con hasta el 5\% de serrín, es una alternativa válida para el reciclaje de residuo agrícola y su comportamiento mecánico ante sismos es satisfactorio.

PALABRAS CLAVE: Ladrillo; Aditivo orgánico; Propiedades mecánicas; Terremoto; Modelización; Análisis de elementos finitos

ORCID ID: D. Dominguez (http://orcid.org/0000-0001-6664-9011); P. Muñoz (http://orcid.org/0000-0001-7958-1271); L. Muñoz (http://orcid.org/0000-0001-9970-6289)

Copyright: (C) 2017 CSIC. This is an open-access article distributed under the terms of the Creative Commons Attribution License (CC BY) Spain 3.0. 


\section{INTRODUCTION}

Construction building materials were widely developed during the last decades, with the aim of both improving thermal or mechanical behaviour and reducing the equivalent $\mathrm{CO}_{2}$ foot print. These targets try to minimise the high-energy impact of buildings, which accounts for more than $39.6 \%$ of worldwide energy consumption and $40 \%$ of total greenhouses gas emissions (1) by reducing the embodied energy of raw materials while building structure is not compromised. Lately, one of the most explored areas for improving construction materials is the use of certain wastes within the raw materials to achieve the so-called lightweight products, which have clearly shown enhanced thermal properties as insulators. In particular such researches have focused on the fired clay brick industry due to the high temperatures involved in the firing stage of manufacture $(2,3)$. Despite worldwide fired clay bricks being the most used construction materials for dwellings, the development of high-performance concrete since the 1990's has contributed to a reduction in brick market share (4). Regardless of this, fired clay materials, such as tiles, roof tiles or bricks, are currently extensively used in the construction sector. These products typically show better thermal properties for insulation than others, however, the manufacturing process highly impacts the embodied energy, soils and greenhouse gas emissions for three main reasons: (i) the high energy intensity required for the firing process, (ii) the $\mathrm{CO}_{2}$ emissions produced by both the melting process of clay minerals and used fuel and (iii) due to the large amount of required raw matter, which is removed from quarries. Hence, with the aim of reducing these negatives impacts this paper investigates the replacement of certain amounts of clay with organic residue, such as sawdust.

In many countries located in seismic zones, fired clay bricks have replaced by others that have lower thermal insulation properties but show higher mechanical resistance. For example, in Japan after the Kanto earthquake (1923) fired clay brick masonry was almost all replaced by concrete or wood panels (5). However, in developing countries, such as Turkey (6), Nepal (7) or Peru (8) among others, brick masonry walls (infill walls) are still the most extended solution for enclosures. For example, in Chile, houses of one story represent $60 \%$ of the total building constructions and more than $43 \%$ of their wall-surface are still made using fired clay bricks, according to the National
Statistic Institute (9) and the Chilean Construction Chamber (10).

On the other hand, previous researches showed that buildings with frames (beams and columns) of low height, behave better with the introduction of infill walls $(11,12)$. This constructive solution does not require great expertise when is applied only in symmetrical placement plans and elevations, which implies lower economic and environmental impact than other more complex mounting systems.

With the aim of contributing to the use of the lightweight materials that can positively impact on bot; energy savings and wastes recycling policies (13), this paper reports on the mechanical behaviour of lightweight brick masonry (infill walls) for houses of one story. Bricks were made by adding agricultural wastes, in particular sawdust from vine shoots (SW), which are produced in large quantities each season by Chilean vineyards and are currently disposed of in landfills without any revalorisation. Such test specimens are tested following international standards and it is demonstrated that they might be used in seismic zones with better results than other fired clay bricks more commonly used.

\section{MATERIALS}

\subsection{Fired clay bricks used for enclosures}

Fired clay samples were manufactured in partnership with a brick factory and were made by following the standard production procedures of the partner factory and the laboratories and workshops of the university. Clay was collected from the output of the homogenisation pit. Here, raw material from the quarry is crushed, mixed and left for weeks. Therefore a homogeneous mass, in terms of granulometry and moisture, is obtained. Raw material from the quarry was analysed for minerals by the chemical faculty of University of Seville using X-Ray Diffraction (XRD) and chemical composition was determined by the Carpi Laboratory. These characteristics are summarised in Table 1 .

Samples were mineralogically analysed by XRD using a Bruker D8 Advance instrument with a scanning speed of $0.5^{\circ}(2 \theta) / \mathrm{min}, 0.15$ step/size, and $\mathrm{Cu}-\mathrm{k} \alpha$ radiation $(40 \mathrm{kV}, 30 \mathrm{~mA})$ in the General Facilities for Research of the University of Seville (CITIUS).

Mineral composition has been determined by following the Quantitative Interpretation of Mineralogical Composition from X-Ray and Chemical data for the Pierre Shale. Thus the used clay is composed by $29 \%$ quartz, $12 \%$ calcite, $57 \%$

TABLE 1. Clay chemical composition

\begin{tabular}{cccccccccc}
\hline & $\mathbf{S i O}_{2}$ & $\mathbf{T i O}_{2}$ & $\mathbf{A l}_{2} \mathbf{O}_{3}$ & $\mathbf{F e}_{2} \mathbf{O}_{3}$ & $\mathbf{M g O}$ & $\mathbf{C a O}$ & $\mathbf{N a}_{2} \mathbf{O}$ & $\mathbf{K}_{2} \mathbf{O}$ & $\mathbf{L O I}$ \\
\hline Dry weight percentage & $48.32 \%$ & $0.83 \%$ & $19.75 \%$ & $5.07 \%$ & $2.30 \%$ & $7.71 \%$ & $0.79 \%$ & $2.93 \%$ & $16.08 \%$ \\
\hline
\end{tabular}


Phyllosilicates, $2 \%$ feldspar and some traces of goethite (See in Figure 1).

The new raw material (clay and SW) was mixed by dry method. Thus, no additional water was used for mixing excepting the moisture of raw materials. Three batches were then formed with 5\% (ASa), $11 \%(\mathrm{ASb})$ and $17 \%$ (ASc) of SW. A single control batch without additive (AA) was also made. These percentages were chosen with the aim of comparing results with similar previous research but also investigating new percentages, as is stated in results section. All specimens, regardless of their percentage of additive, were manufactured by adding $20 \%$ of molding water and mixed by a 5-litre capacity laboratory mixer in order to form samples of $300 \times$ $300 \times 20 \mathrm{~mm}$ by pressing at $2.5 \mathrm{MPa}$. Since the focus of this research is to show material behaviours, without paying attention to the bricks geometry, the sample form was selected by taking into account the factory process requirements in order to not influence this variable. After samples were carefully demolded, the drying and firing processes were conducted. The drying stage consisted of exposing test samples to different atmospheres that range from $36^{\circ} \mathrm{C}$ and $90 \%$ relative humidity $(\mathrm{RH})$ to $100^{\circ} \mathrm{C}$ with less than $5 \%$ of H.R. The fired samples were finally measured, weighed and tested by paying attention to its planimetry using tapered calibration wedges. After this quality control stage, test specimens were fired at $950^{\circ} \mathrm{C}$ following the standard thermal process set up in the tunnel kiln.

\subsection{Building model}

In this study, a building of one story and rectangular plant of $10 \times 8$ meters (Figure 2 ) was modelled. This type of was chosen because of it is the most extensive construction in Chile and other countries that experience seismicity. This detached house is commonly built using a reinforced concrete structure with frames of beams and columns. Its dimensions and characteristics are detailed in Table 2. It can be seen that the use of fired clay brick walls highly reduce the fundamental period of the building. This fundamental period $\left(T_{o}\right)$ of a building represents the duration of a complete cycle of vibration (go and return). It could be defined as the inverse of the frequency $\left(w_{o}\right)$ as it follows [Eq. 1,2].

$$
T_{o}[s]=\frac{1}{w_{o}}
$$

Where $T_{o}$ is a function of the mass $(m)$ and stiffness $(k)$ of the building that depends on each axis (X, Y).

$$
T_{o}[s]=2 \cdot \sqrt{\frac{m}{k}}
$$

Where $m$ and $k$ are the mass and the modulus of elasticity, respectively.

The floor slab is also made of reinforced concrete with a thick depth of $15 \mathrm{~cm}$. The resistances

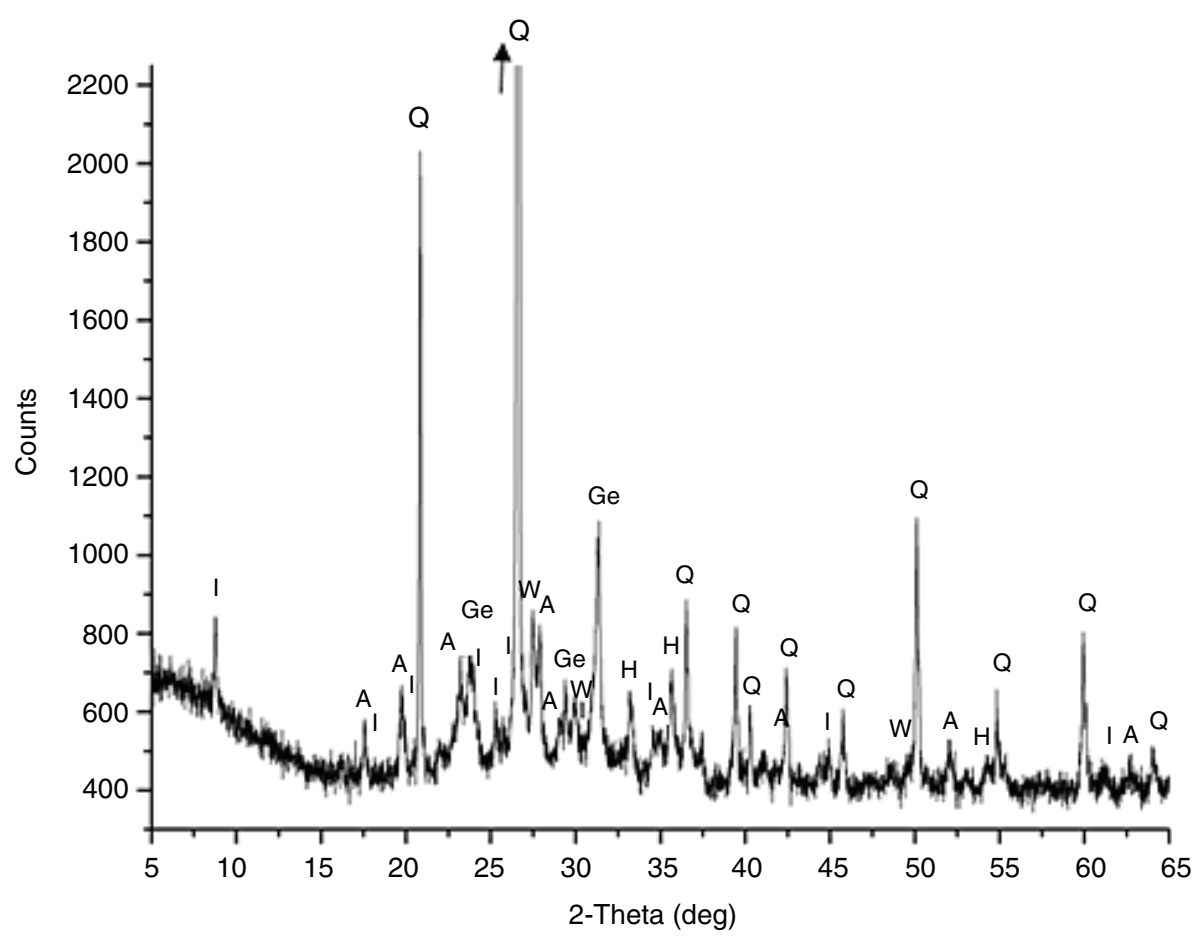

FIGURE 1. Fired Clay XRD Q = Quartz, $\mathrm{Ca}=$ Calcite, $\mathrm{I}=$ Illite, $\mathrm{K}=$ Kaolinite, $\mathrm{F}=$ Feldespat $, \mathrm{Cl}=\mathrm{Chlorite}, \mathrm{G}=\mathrm{Goethite}$. 

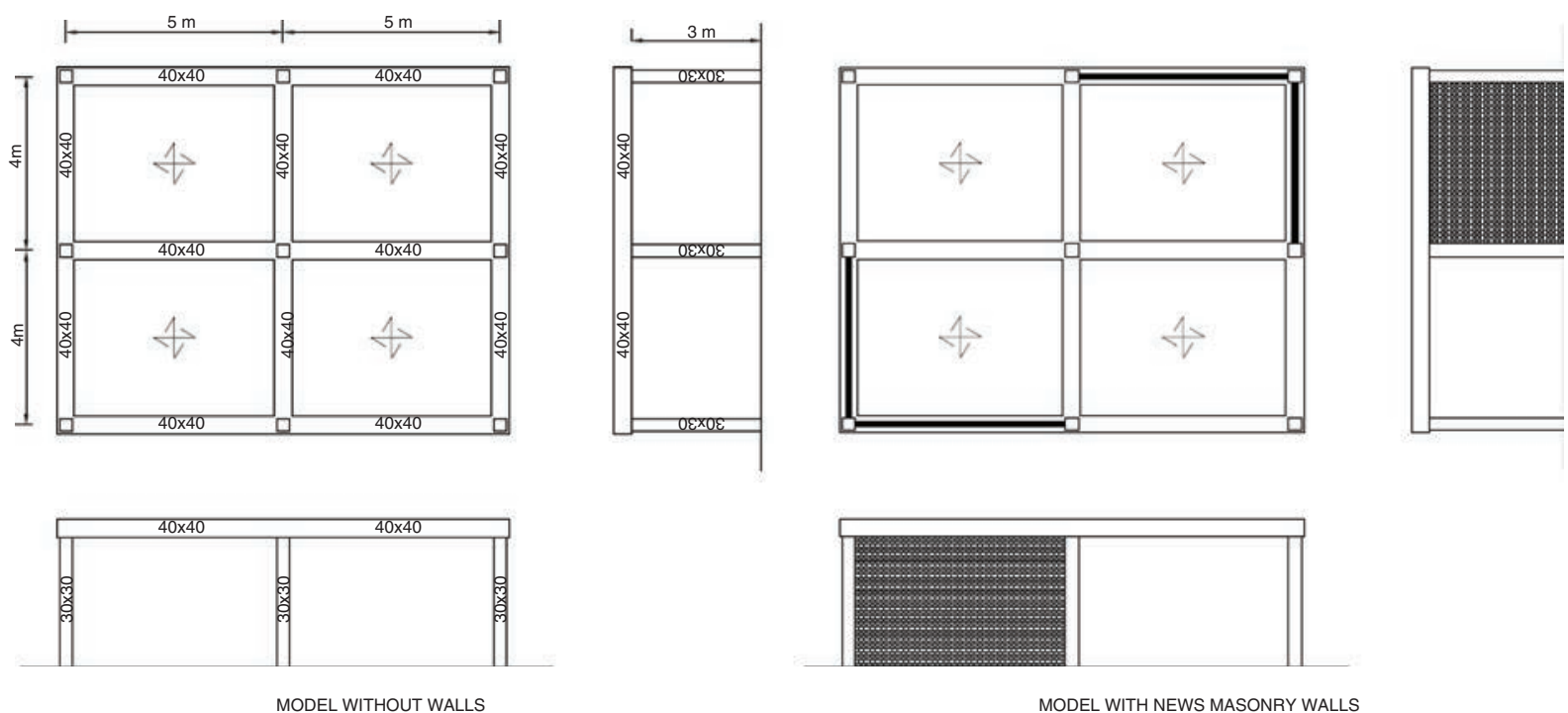

FiguRE 2. Structural design of buildings considered.

TABLE 2. Type, period and building dimensions

\begin{tabular}{lcccc}
\hline Building type & Dimension columns $(\mathbf{X}, \mathbf{Y}) \mathbf{( c m})$ & Dimension beams $\mathbf{( X , \mathbf { Y } ) ( \mathbf { c m } )}$ & Type of brick & Fundamental Period (s) \\
\hline B1 & $30 \times 30$ & $40 \times 40$ & None & 0.265 \\
B2 & $30 \times 30$ & $40 \times 40$ & AA00 & 0.071 \\
B3 & $30 \times 30$ & $40 \times 40$ & ASa & 0.150 \\
B4 & $30 \times 30$ & $40 \times 40$ & ASb & 0.143 \\
B5 & $30 \times 30$ & $40 \times 40$ & ASc & 0.099 \\
B6 & $30 \times 30$ & $40 \times 40$ & Perforated & 0.0644 \\
\hline
\end{tabular}

of the typically materials used in this structures are: $f_{c}=30 \mathrm{MPa}$ for concrete and steel A630-420H. The distances between columns are $5 \mathrm{~m}$ in the $\mathrm{X}$-axis and $4 \mathrm{~m}$ in the Y-axis.

Two situations were analysed: without walls and with walls symmetrically placed (floor to floor) using the aforementioned series of added bricks and the typical perforated brick used in construction, which is made without any waste additives. The properties of perforated bricks were considered following the recommendations of the Standard CTE SE-F; brick strength is stated as $200 \mathrm{~kg}$ per $\mathrm{cm}^{2}$ with a mortar (M80) joint thickness of $1-1.5 \mathrm{~cm}$. A thickness of $12 \mathrm{~cm}$ for bricks is considered in all analysis. For modelling the walls we used the Mostafaei and Kabeyasawa (14) method with the software SEISMOSTRUCT ${ }^{\circledR}(15)$, which is used for determining the shear and compression values of the walls. This method considers the dimensions of the masonry wall and the type of brick (geometry, strength, stiffness, Young's modulus, strain, etc...). In addition the mounting method of the brick, its bonding conditions must be defined as well as the type of mortar and the friction coefficient depending on the type of brick, in accordance with Eurocode 06 (EN1996) (16). The compression strength (CS) of mortar is considered to be $8 \mathrm{MPa}$. The analysis does not take into account the attachment of the walls with the building structure since this used to be done by applying Expanded Polystyrene Foam (EPF). The detail union of the armed beam-column is shown in Figure 3.

\section{METHODOLOGY}

\subsection{Testing brick samples}

Firstly, fired samples were tested by using Archimedes method in accordance with EN 772-13:2000 (17) and EN 772-3:1998 (18). Thus, samples were immersed in water until constant weight was achieved (Ww), then taken out, wiped dry and weighed (Ws) in a saturated state. Finally samples were oven-dried until constant weight and re-weighed $(\mathrm{Wd})$. Therefore, in accordance with (19), bulk density (BD) may be calculated as follows [Eq.3]: 


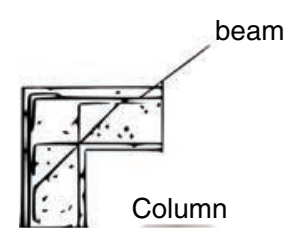

Corner detail reinforced beam - column

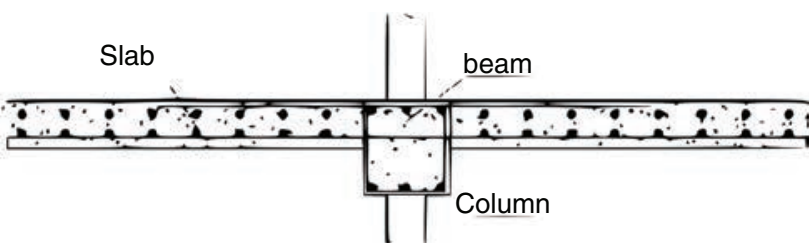

Corner detail reinforced beam - column

FIgURE 3. Detail union of the armed beam-column.

$$
\text { Bulk Density }[\%]=\frac{W_{d}}{W_{s}-W_{w}}
$$

Where:

$W_{w}=$ Immersion on water weight

$W_{s}=$ Saturated wet state weight

$W_{d}=$ Dried weight

Compression tests were conducted on the test specimens using a SERVOSIS ${ }^{\circledR}$ series MES AV universal compression test machine. Before testing, moisture was removed from specimens by drying in an oven at $110^{\circ} \mathrm{C}$ until constant weight was achieved, in order to offset any rehydration. Then, at least 10 random cylinders were obtained from each fired sample using a diamond cutter head mounted on a column drill, which provides cylindrical specimens of approximately $19 \mathrm{~mm}$ diameter and $20 \mathrm{~mm}$ height. This test machine includes a load application rate control module, which prevents any error due to the load applying speed. In accordance with UNE 67-026:2002 assays took, at least, more than 60 seconds, otherwise ultimate breaking stress results might be higher than the real ones, as was demonstrated by (20).

\subsection{Modelling the building simulation}

The analyses were performed using the program of structural analysis finite element SEISMOSTRUCT ${ }^{\circledR}$ 7.0.2. The modelling of these buildings was carried out with a processor finite bar element, which was implemented with the developed formulations demonstrated by (21-25). The cross sections of each structural element (columns and beams) and the characteristics of the construction materials were specified following models proposed by Bento et al (26).

The columns, beams and slab floors are represented by a nonlinear finite element bar (27); the non-linearities are concentrated in plastic hinges (28); $15 \%$ of the overall length dimension of each element of these regions is considered to be in accordance with previous research (29-31); the joints between the columns and beams are considered as rigids; the hysteretic behaviour of joints are represented for the distribution of stress-strain of the material properties and of the shape and number of the structural element fibres (each section is discretised with 300 fibres).
The slab floors were determined as rigid diaphragms restricting the movement in the $Z$ plane $(\mathrm{X}, \mathrm{Y})$. The forces are applied on the beams or horizontal linear elements.

The masonry walls model was carried out by elements "infill panel" that connect adjacent plants (avoiding the effect of plastic hinges); walls were treated as masonry elements defined by four nodes, developed and programmed by Smyrou et al (32) and implemented within the Seismostruct ${ }^{\circledR}$ software. Six struts represented each panel. The parameters used for discretising these struts at compression, were defined by their stress-strain curve response, which was obtained by testing the manufactured test specimens as described above. In addition, based on such curves, the secant elasticity or the so-called Young's module (YM), was calculated. In the case of concrete, a standard CS equal to $8 \mathrm{MPa}$ was considered since it is the minimum value stated by the Eurocode 08 (33). For vertical and horizontal joints a coefficient of friction of 0.66 was used, in accordance with Eurocode 06 (34).

Initial stiffness (elastic) walls were estimated as twice the final stiffness in accordance with (35). This formulation suggests that initial stiffness (elastic) walls is the ratio between the strength and the last displacement. The strength and stiffness of the walls are determined based on the aforementioned strut and tie model (35).

The seismic behaviour of the buildings and the adopted solutions were analysed by considering the capacity curves. These were carried out by nonlinear static analysis ("push-over") and nonlinear dynamic analysis of accelerograms according to high magnitude size. Dynamic analysis is performed based on the Chusmiza earthquake record. The Chusmiza earthquake took place on July $24^{\text {th }}$, 2001 at 5:00 pm in the north of Chile. The earthquake is shown in Figure 4 and shows horizontal accelerograms in two directions, which were used in the dynamic analyses $(36,37)$. This record was chosen because it has a typical average magnitude $\left(M_{w}=6.3\right)$ and was caused by the existence of a double seismic zone located at an intermediate depth and the existence of seismicity located in the Altiplano region. This earthquake caused a death from a falling wall and three people were injured in the village of High Chusmiza. 


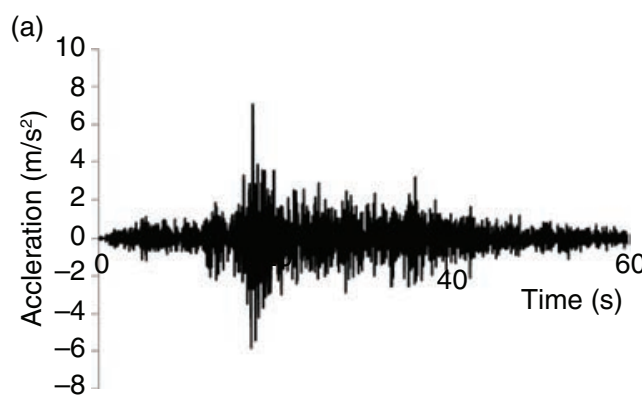

Component North-South (NS)

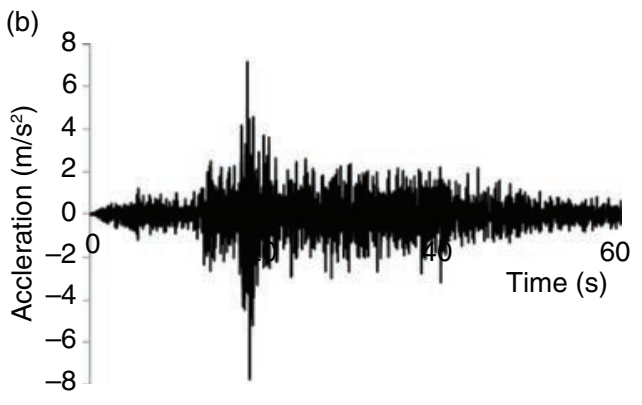

Component East -West (EW)

Figure 4. Earthquake accelerograms for Chusmiza (July 24, 2001) (RENADIC University of Chile, 2001).
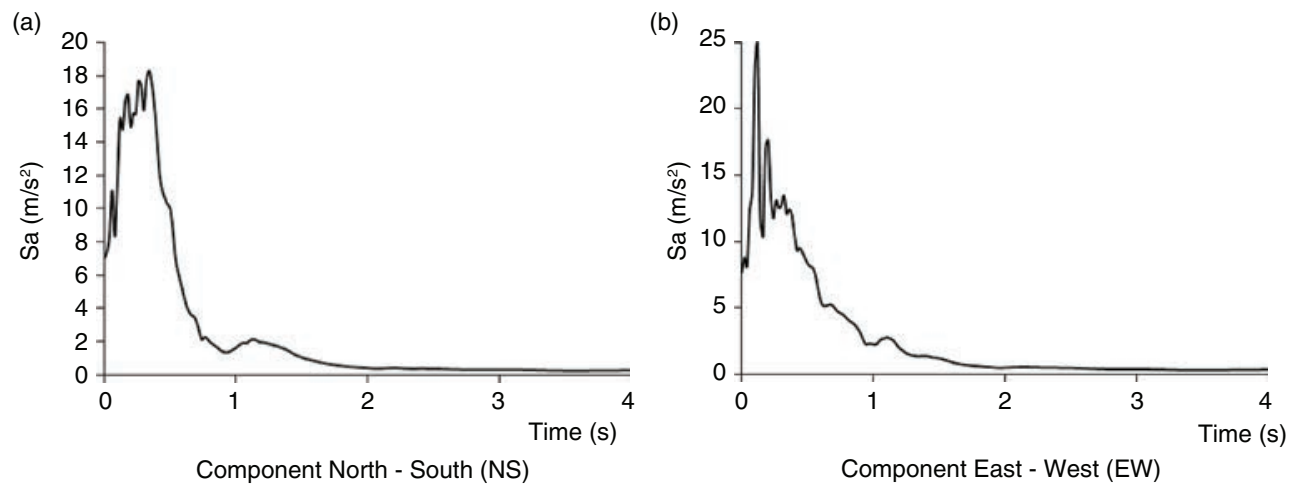

FIGURE 5. Response spectra for Chusmiza (July 24, 2001).

Figure 4 shows that the ground motion records of Chusmiza do not clearly report impulsive character. Earthquakes components, from north to south (Figure 4a) and from east to west (Figure $4 \mathrm{~b}$ ) takes the value of ID $=18.37$ and ID $=15.95$, respectively, in accordance to the Manfredi index (37). This quantifies the speed pulse, which is commonly produced by the proximity to failure, defined as the ratio of the integral of the square of the acceleration along the total length and the product of the maximum values of acceleration and speed. Usually ID values below 10 correspond to impulsive records [Eq.4].

$$
I_{D}=\frac{2 g I_{A}}{\pi V_{\max } a_{\max }}
$$

Regarding the intensity of Arias (38), values can be determined as $0.689 \mathrm{~m} / \mathrm{s}$ for the north-south component and $0,789 \mathrm{~m} / \mathrm{s}$ for the east-west component. These values represent the seismic risk in one area by relating seismic oscillations to the potential building infrastructure damage.

Figure 5 represents the response spectra $\left(S_{a}\right.$ Spectral acceleration) of the acceleration time in each of the components (Figure 4).

\section{RESULTS AND DISCUSSION}

\subsection{Fired samples}

Organic waste burns into the clay matrix at the beginning of firing process, in most cases between $200^{\circ} \mathrm{C}$ and $400^{\circ} \mathrm{C}$ in the so called pre-heating stage, when moisture is removed from the clay matrix. Although, at this point the vitrification phase is not yet started, the surface becomes cratered and some of biggest pores will be remained after firing. Additive placed in the clay matrix, far from the surface, will generate gases, which are trapped into the clay matrix and may react with other minerals to form other structures. In this way it can be assured that the addition of SW to clay produces an increase in porosity. Furthermore this porosity has a great influence on the bulk density, which shows a linear trend against the SW percentage added, implying that all the waste is burned during the firing process. (See Fig. 6). Compression stress (CS) (See Fig. 7) and Young's Module (YM) (See Fig. 8) are also great influenced by this porosity due the effective section lost.

Compression stress (CS) and Young's Module (YM) are also greatly influenced by this porosity due the effective loss. 


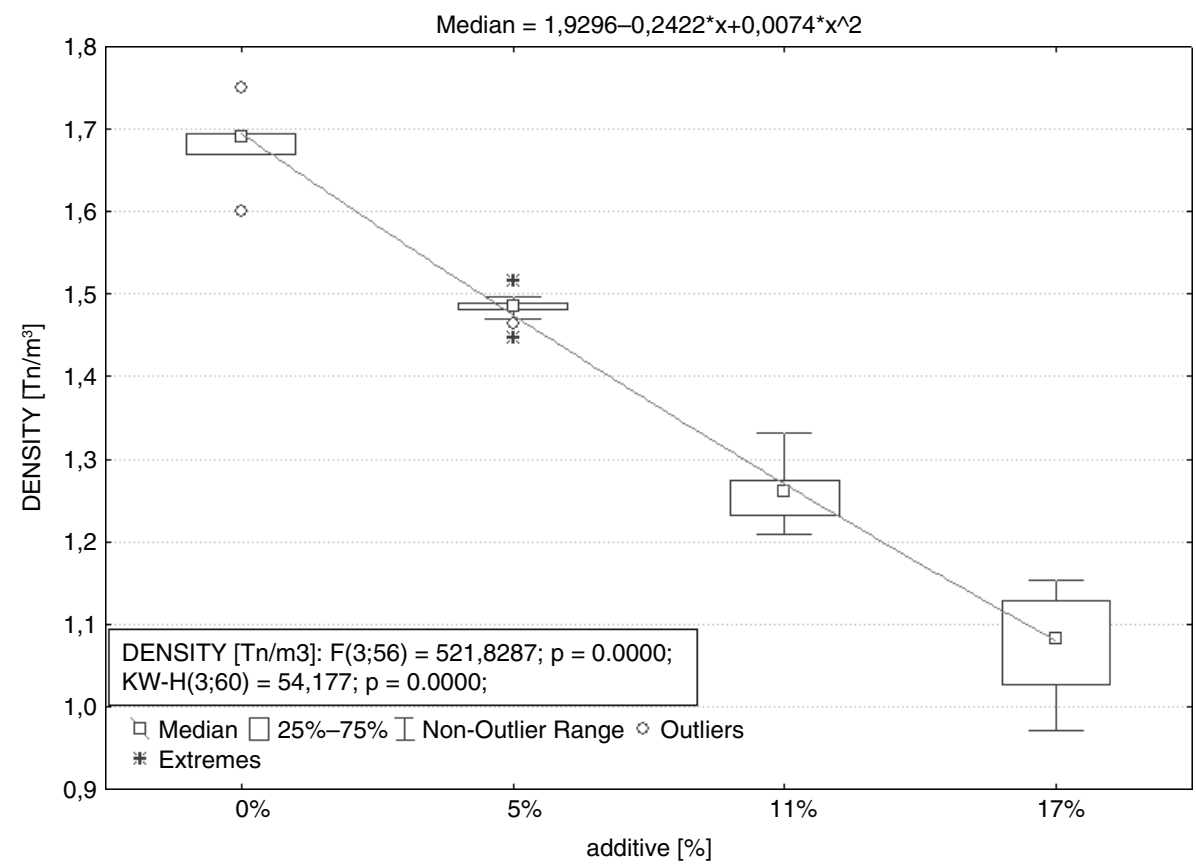

FIGURE 6. BD against percentage of SW added.

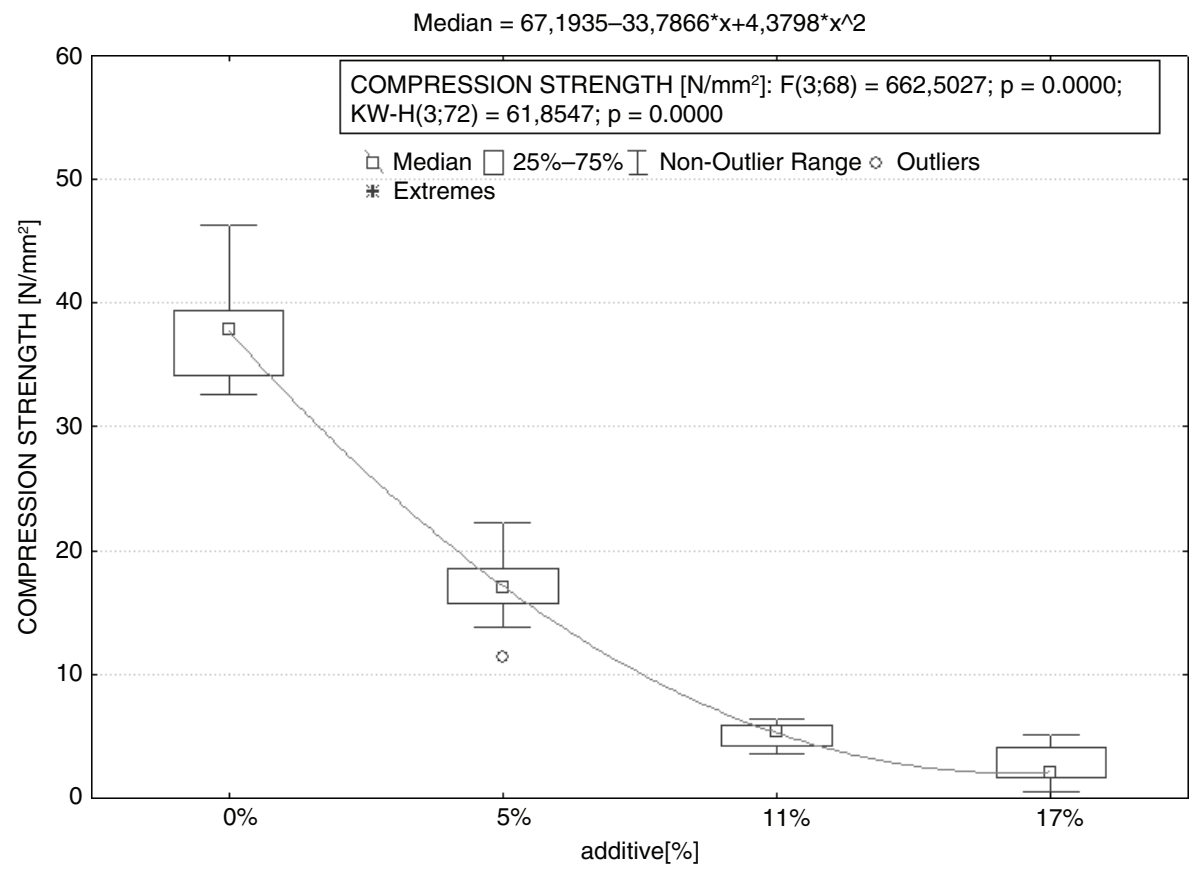

FIGURE 7. Compression stress against percentage of SW added.

CS decays exponentially with the amount of SW added, which limits the potential added percentage. Thus CS is highly reduced by up to $55 \%$ for only $5 \%$ of added SW. From this point, CS is below the minimum normative threshold value, which varies from $10 \mathrm{~N} /$ $\mathrm{mm}^{2}$ for negligible weathering to $20 \mathrm{~N} / \mathrm{mm}^{2}$ in the case of severe weathering in accordance with ASTM C6210 (39) (See Fig. 9). The CS values are similar to those shown in previous researches, with similar firing temperature and raw clay matter. Thus, (40-42) obtained 


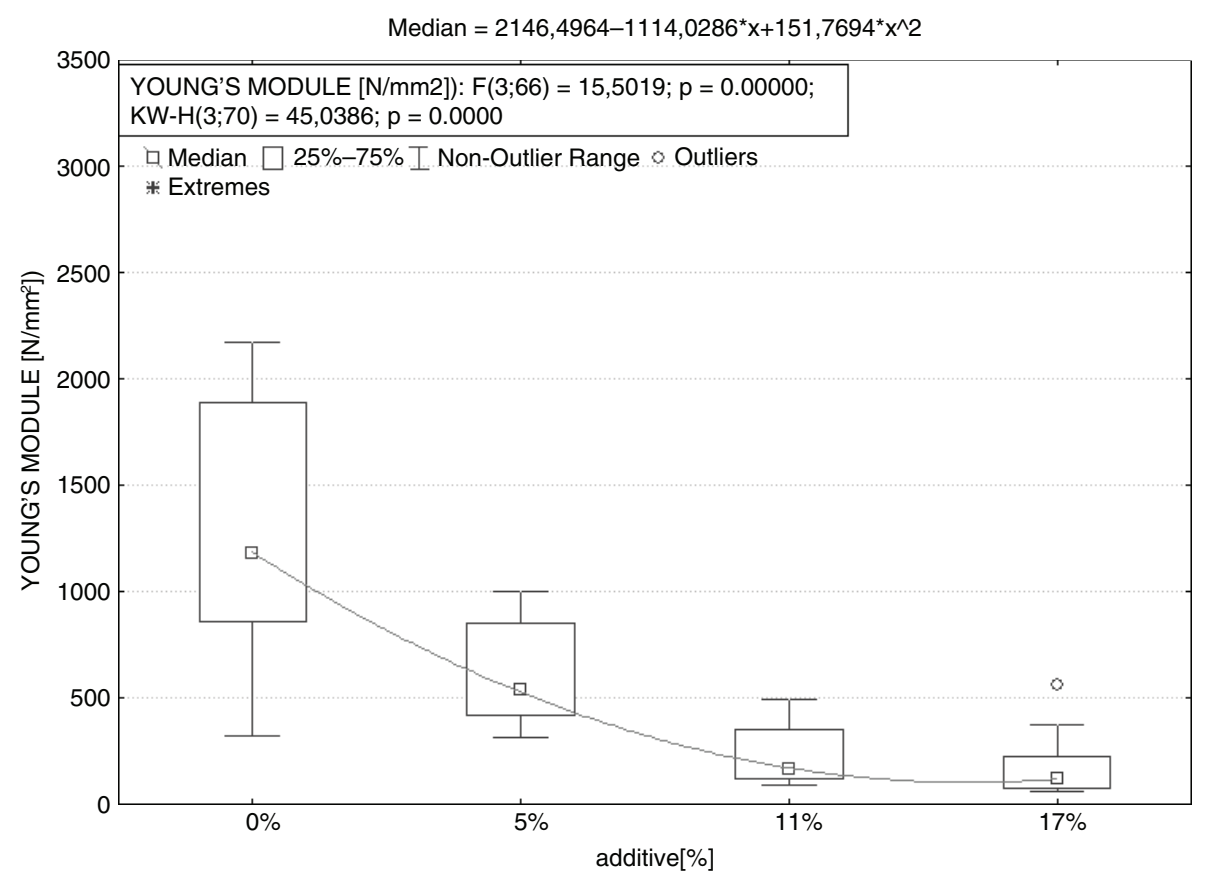

FIGURE 8. Young's Module against percentage of SW added.

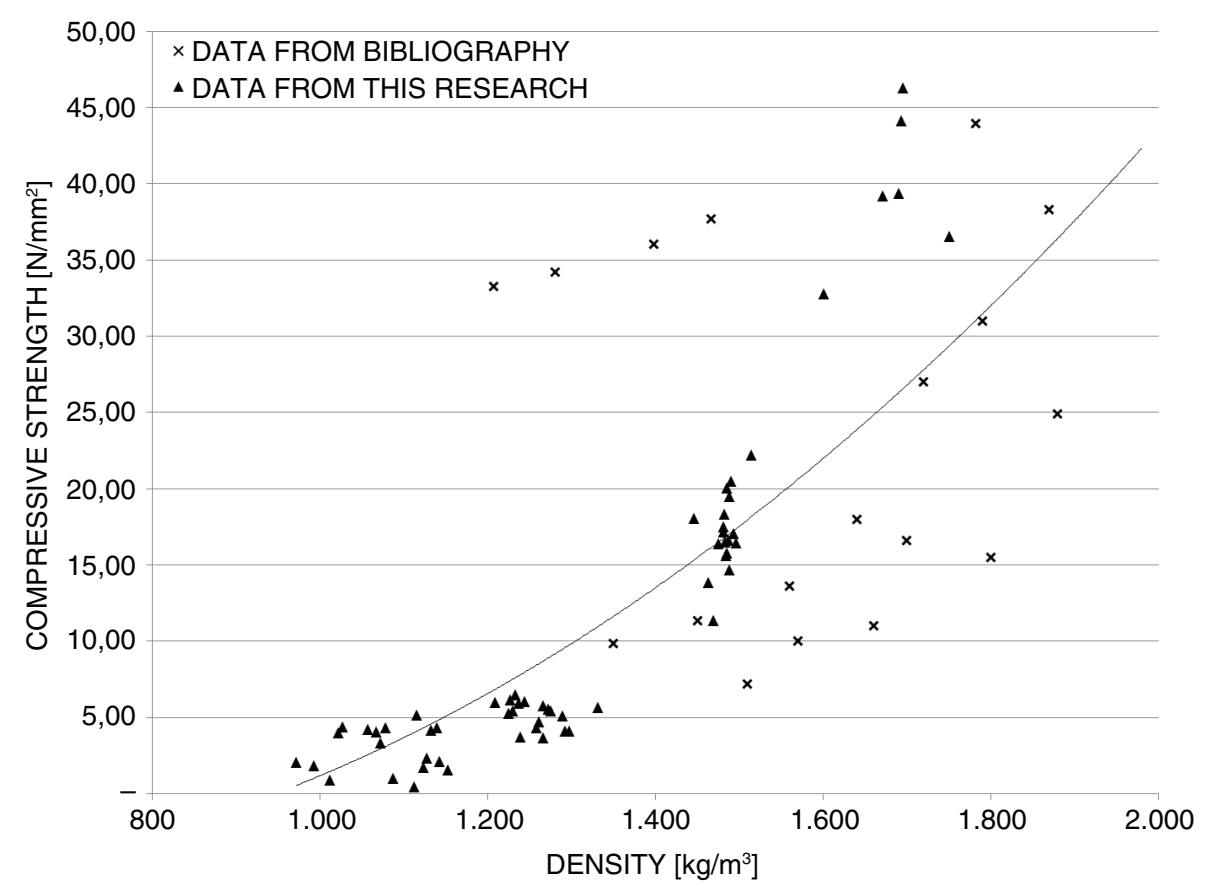

Figure 9. BD against Compressive Strength.

$11.4,27.0$ and $16.9 \mathrm{~N} / \mathrm{mm}^{2}$, respectively when $5 \%$ of sawdust was added, (43) obtained similar values for $4 \%$ of sawdust (approx. $20 \mathrm{~N} / \mathrm{mm}^{2}$ ). However, $(40,41)$ found higher values, than provided by the current research, of $10 \mathrm{~N} / \mathrm{mm}^{2}$ and $9.9 \mathrm{~N} / \mathrm{mm}^{2}$, respectively, when $10 \%$ of SW was added. In the case of (41) this difference may be explained by the higher shaping pressure applied when forming samples (approx. 54 $\mathrm{MPa})$ than that used in this paper $(2.5 \mathrm{MPa})$. In case of (40) the particle size was limited to $1 \mathrm{~mm}$, which 
reduces the size of pores formed and subsequent decreasing of CS. These authors limited the amount of sawdust added to $10 \%$ but (44) shows $3 \mathrm{~N} / \mathrm{mm}^{2}$ for $20 \%$, which is similar to the $2.6 \mathrm{~N} / \mathrm{mm}^{2}$ found in this research.

YM for fired clay samples without any additive reach a maximum of $2.200 \mathrm{~N} / \mathrm{mm}^{2}$, which is lower than that expected according to other research (45). However, it must be noted that this reference does not show firing temperature and mineral composition of fired clay, which are parameters that have a great influence on the mechanical properties of bricks. As additive percentage is increased, YM decreases to an average value of $175 \mathrm{~N} / \mathrm{mm}^{2}$ for the fired samples with $17 \%$ of SW additive. Hence, it can be concluded that waste addition reduces the fragility of fired clay bricks. Table 3 summarises the carried out values for all tests.

\subsection{Nonlinear static analysis "Push over"}

Nonlinear analysis, or the so-called "push over", was implemented for calculating the maximum base shear in the aforementioned building models using triangular distribution forces. This forces-pattern is increased proportionally by a factor $(\lambda)$ to achieve the limit of structural instability (46). The considered options in response are the control results corresponding to displacements. Figure 10 shows the results of capacity curves in each axis $(\mathrm{X}, \mathrm{Y})$ for each type of building case. Here, the significant increase in the base shear of buildings with the introduction of walls should be highlighted, which is in accordance with previous research. The ductility $(\mu)$ of the buildings (Table 4) is similar in both axes. Only the building without walls shows an important increasing for both directions.

\subsection{Dynamic Analysis}

Nonlinear dynamic analysis is performed in discrete time using the $b$-Newmark method. The period of time discretisation $(\mathrm{D} t)$ is $0.025 \mathrm{~s}$. A Rayleigh Model represents the damping of the structure (47) wherein, the damping factor is equal to $5 \%$. Figure 11 shows the analysis response dynamic in each axis $(\mathrm{X}, \mathrm{Y})$ for each type of analysed building. Moreover, it shows that solid bricks without additive

TABLE 3. Summary of mean values and standard deviation (-) of physical and mechanical properties

\begin{tabular}{|c|c|c|c|}
\hline Percentage of Additive [\%] & $\mathrm{CS}\left[\mathrm{N} / \mathrm{mm}^{2}\right]$ & $\mathrm{E}\left[\mathrm{N} / \mathrm{mm}^{2}\right]$ & BD $\left[\right.$ Ton $\left./ \mathrm{m}^{3}\right]$ \\
\hline 0 & $38.1(4.5)$ & $1,812.2(1,821.5)$ & $1.68(0.05)$ \\
\hline 5 & $17.15(2.5)$ & $617.6(223.0)$ & $1.48(0.01)$ \\
\hline 11 & $5.07(0.9)$ & $211.4(120.4)$ & $1.26(0.03)$ \\
\hline 17 & $2.63(1.4)$ & $173.5(129.5)$ & $1.08(0.06)$ \\
\hline
\end{tabular}

(a)

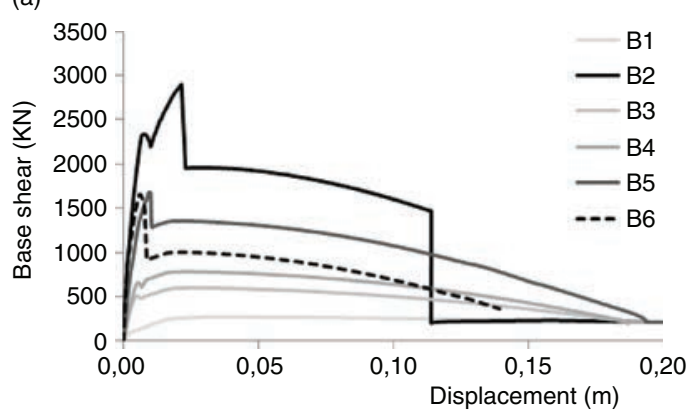

$\mathrm{B}(\mathrm{x})$ (b)

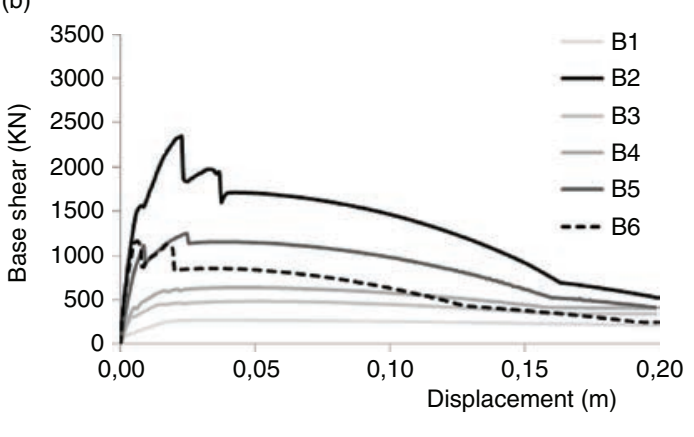

$B(y)$

FIGURE 10. Capacity curves "Push over" considered buildings.

TABLE 4. Ductility of considered buildings

\begin{tabular}{lcccccc}
\hline Ductility & B1 & B2 & B3 & B4 & B5 & B6 \\
\hline$\mu(\mathrm{X})$ & 7.32 & 2.94 & 3.00 & 3.01 & 3.36 & 3.10 \\
$\mu(\mathrm{Y})$ & 5.76 & 3.34 & 4.24 & 4.31 & 4.55 & 4.03 \\
\hline
\end{tabular}



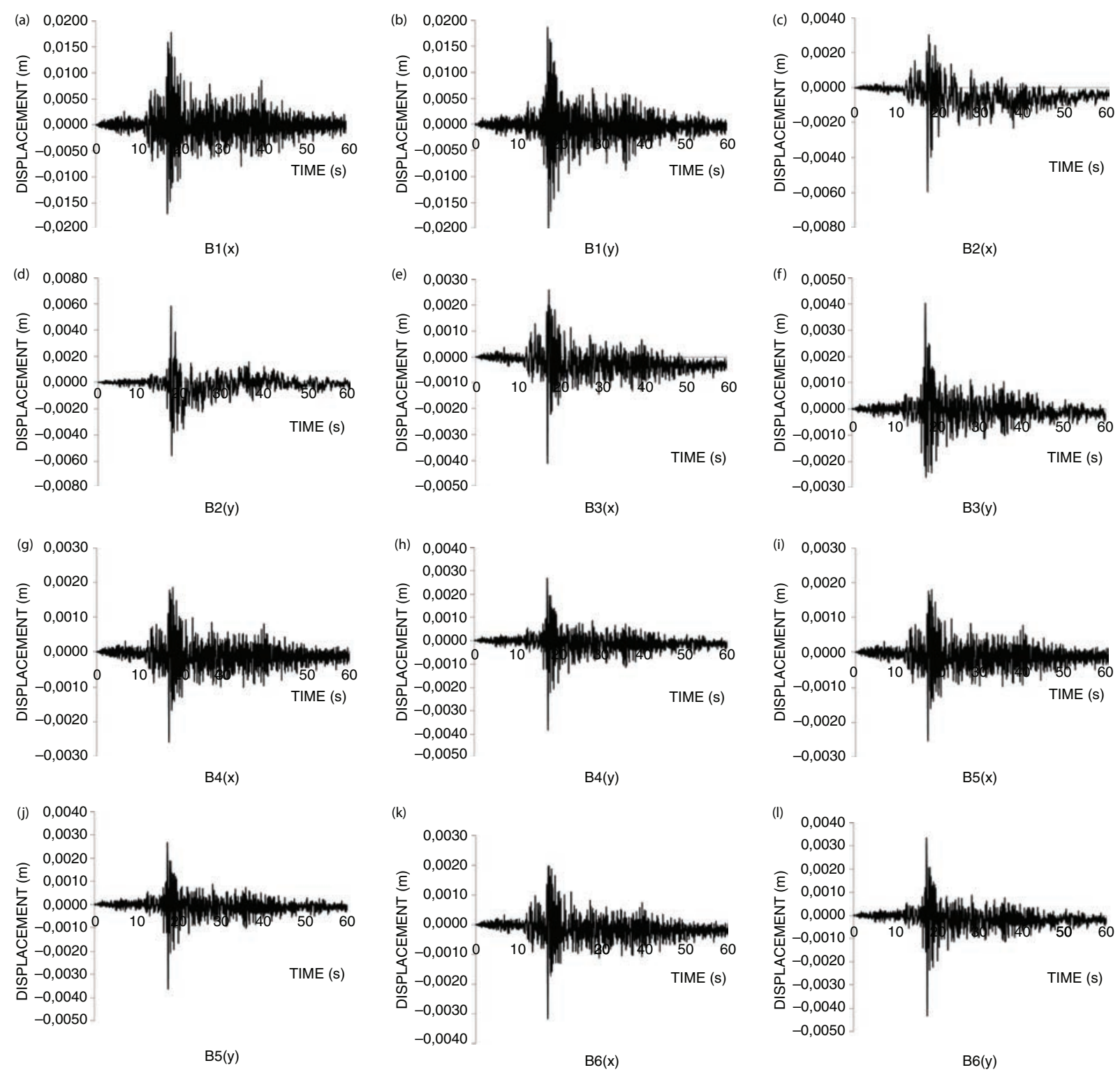

FIGURE 11. Dynamic analysis of considered buildings.

produce the best response. Specimens made by adding $5 \%$ of SW show better behaviour than the commercial perforated bricks. This can be explained by the energy that can be absorbed by each type of fired sample. Hence, those samples manufactured by adding $11 \%$ and $17 \%$ of SW show the worst response, which is similar to the one produced by the building without walls. The aforementioned analysis for the $\mathrm{X}$ and $\mathrm{Y}$ directions of the earthquake corresponds to $\mathrm{X}$ and $\mathrm{Y}$ direction of building, respectively.

\section{CONCLUSIONS}

New fired clay bricks specimens made by adding sawdust from vine shoots were made and tested. BD varies proportionally to the amount of additive and CS shows a non-linear variation. Hence, CS decreased $55 \%$ when $5 \%$ of SW is added, approximately $87 \%$ when $11 \%$ is added and samples with $17 \%$ of SW display initial CS reduced by up to $95 \%$. The same trend was observed in the YM variation. Hence BD is not the best index for estimating neither CS nor YM when fired clay bricks are used.

With this test data, an individual one-story house was modelled and simulated against a high earthquake intensity based on the spectra of the Chusmiza earthquake. It is shown that the best results were obtained using bricks without additive. However bricks made by adding $5 \%$ of vine-shoot sawdust (B3) were highlighted as optimal, even above the typically perforated brick. 
Therefore the maximum base shear strength is achieved by those enclosure buildings made by bricks without additive (B2) and it is twice that achieved by both bricks with $5 \%$ of additive (B3) and perforated bricks (B6). Furthermore, this maximum base shear strength is around 10-times that of the building without walls.

The maximum shear strength, for building with bricks made by adding $17 \%$ of sawdust (B5) showed the least strength. However, this value is about twice that of buildings without walls (B1).

The ductility of the buildings is similar for all buildings with walls. However, in case of building, modelized without walls, ductility has been shown an important increasing.

Thus, it is demonstrated that lightweight materials may be an alternative for building the enclosures of individual one-story houses, even when such buildings are built in seismic zones.

\section{ACKNOWLEDGMENTS}

We would like to specially acknowledge the participation in this research of the University of Seville, which has granted the use of their facilities as well as specialized staff, in particular Emilio Galán, Ph.D. and Isabel González, Ph.D. who have developed the XRD assays. In addition we must highlighted that this research is part of the Project DIP74-2016, funded by Universidad Autonoma de Chile.

\section{REFERENCES}

1. Raji, B.; Tenpierik, M.J.; Van Den Dobbelsteen, A. (2015) The impact of greening systems on building energy performance: A literature review. Renew. Sust. Energ. Rev., 45, 610-623. https://doi.org/10.1016/j.rser.2015.02.011

2. Muñoz V.P.; Morales, M.P.; Mendívil, M.A.; Muñoz, V.L. (2014) Fired clay bricks manufactured by adding wastes as sustainable construction material: A review. Construcc. Build. Mat., 63 97-107. https://doi.org/10.1016/j. conbuildmat.2014.03.045

3. Raut, S.P.; Ralegaonkar, R.V.; Mandavgane, S.A. (2011) Development of sustainable construction material using industrial and agricultural solid waste: A review of wastecreate bricks. Construcc. Build. Mat., 25, 4037-4042. https://doi.org/10.1016/j.conbuildmat.2011.04.038

4. Bories, C.; Borredon, M.; Vedrenne, E.; Vilarem, G. (2014) Development of eco-friendly porous fired clay bricks using pore-forming agents: A review. J. Environ. Manage., 143, 186-196. https://doi.org/10.1016/j.jenvman.2014.05.006

5. Cuadra, C.; Tokeshi, K.; Karkee, M.B.; Sakaida, Y. (2007) Earthquake resistance of a historical brick building in Akita Prefecture, Japan. Wit Trans. Built. Env., 95, 699-707. https://doi.org/10.2495/STR070651

6. Lsik, I.; Uz, V. (2013) Turkey's clay brick and tile industry - History, present and future, Ziegelindustr. Int., 9, 22-29.

7. Haack, B.N.; Khatiwada, G. (2007) Rice and Bricks: Environmental Issues and Mapping of the Unusual Crop Rotation Pattern in the Kathmandu Valley, Nepal. Environ. Manage., 39(6), 774-782. https://doi.org/10.1007/ s00267-006-0167-0

8. Lavado, L.; Taira, J; Gallardo, J. (2014) Current state of masonry properties material on emerging zones in Lima city. J. Disaster Res., 9(6), 1015-1020.
9. INE (2015). Website of the Instituto Nacional de Estadística de Chile. (Spanish). Available at: http://ine.cl (July 2015).

10. CChC (2011). Website of the Cámara Chilena de la Construcción. Anuario de la construcción 2011 (Spanish). Available at: http://www.cchc.cl (July 2015).

11. López-Almansa, F; Domínguez, D.; Benavent-Climent, A. (2013). Seismic performance of RC buildings with wide beams. Eng. Struct., 42(1), 687-702. https://doi. org/10.1016/j.engstruct.2012.08.033

12. Domínguez, D.; López-Almansa, F.; Benavent-Climent, A. (2014) Comportamiento, para el terremoto de Lorca de 11-05-2011, de edificios de vigas planas proyectados sin tener en cuenta la acción sísmica, Inf. Constr., 66(533) (spanish). https://doi.org/10.3989/ic.12.092

13. Phonphuak N.; Chindaprasirt, P. (2015) Types of waste, properties, and durability of pore-forming wastebased fired masonry bricks, In Eco-Efficient Masonry Bricks and Blocks, Chapter 6, Woodhead Publishing, Oxford, 2015, pp. 103-127. https://doi.org/10.1016/ B978-1-78242-305-8.00006-1

14. Mostafaei H.; Kabeyasawa T. (2004) Effect of Infill Masonry Walls on the Seismic Response of Reinforced Concrete Buildings. Bull. Earthquake Res. Ins. 79, 133-156.

15. Seismosoft ${ }^{\circledR}$ "SeismoStruct v7.0.2 - A computer program for static and dynamic nonlinear analysis of framed structures," available from http://www.seismosoft.com, (July 2015).

16. EN 1998 (Eurocode 8). Disposición para el Proyecto de estructuras sismorresistentes. (2005).

17. EN 772-13:2000. Methods of test for masonry units - Part 13: Determination of net and gross dry density of masonry units (except for natural stone).

18. EN 772-3:1998. Methods of test for masonry units - part 3: Determination of net volume and percentage of voids of clay masonry units by hydrostatic weighing.

19. Velasco, P.M.; Ortiz, M.P.M.; Giró, M.A.M.; Melia, D.M.; Rehbein, J.H. (2015). Development of sustainable fired clay bricks by adding kindling from vine shoot: Study of thermal and mechanical properties. Appl. Clay Sci., 107 156-164 https://doi.org/10.1016/j.clay.2015.01.017

20. Huang, S.; Liu, H.; Xia, K. (2014) A dynamic ball compression test for understanding rock crushing. Rev. Sci. Instrum., 85 (12-1), 123902. https://doi.org/10.1063/1.4902836

21. Neuenhofer, A.; Filippou, F.C. (1997) Evaluation of nonlinear frame finite-element models. J. Struct. Eng-ASCE, 123(7), 958-966.

22. Park, Y.J.; Ang, A.H.S (1985) Mechanistic seismic damage model for reinforced concrete. J. Struct. EngASCE, 111 (4), 722-739. https://doi.org/10.1061/ (ASCE)0733-9445(1985)111:4(722)

23. Huang, Z.M.; Chen, T. (2003) Comparison between flexibility-based and stiffness-based nonlinear beam-column elements. Gongcheng Lixue, 20 (5), 24-31.

24. Li, S.; Zhai, C.H.; Xie, L.L. (2009) Review of flexibilitybased finite element method for beam-column elements. $J$. Harbin Inst. Technol., 16(1), 81-86.

25. Alemdar, B.N.; White, D.W. (2005) Displacement, flexibility, and mixed beam-column finite element formulations for distributed plasticity analysis. J. Struct. Eng-ASCE, 131(12), 1811-1819. https://doi.org/10.1061/ (ASCE)0733-9445(2005)131:12(1811)

26. Bento, R.; Bhatt, C.; Pinho, R. (2010) Using nonlinear static procedures for seismic assessment of the $3 \mathrm{D}$ irregular SPEAR building. Earthqu. Struct., 1(2), 177-195.

27. Mostafa, M.; Sivaselvan, M.V; Felippa, C.A. (2013) Reusing linear finite elements in material and geometrically nonlinear analysis - Application to plane stress problems. Finite. Elem. Anal. Des., 69, 62-72. https://doi. org/10.1016/j.finel.2013.02.002

28. Scott, M.H.; Fenves, G.L. (2006) A plastic hinge simulation model for reinforced concrete members. $17^{\text {th }}$ Anal. Comput. Spec. Conf., 7. https://doi.org/10.1061/40878(202)16

29. Karatarakis, A.; Metsis, P.; Papadrakakis, M. (2013) GPUacceleration of stiffness matrix calculation and efficient initialization of EFG meshless methods. Comput. Methods Appl. Mech. Eng., 258, 63-80. https://doi.org/10.1016/j. cma.2013.02.011 
30. Montella, G.; Calabrese, A.; Serino, G. (2014) Mechanical characterization of a Tire Derived Material: Experiments, hyperelastic modeling and numerical validation. Construcc. Build. Mat., 66, 336-347. https://doi.org/10.1016/j. conbuildmat.2014.05.078

31. Spizzuoco, M.; Calabrese, A.; Serino, G. (2014) Innovative low-cost recycled rubber-fiber reinforced isolator: Experimental tests and Finite Element Analyses. Eng. Struct., 76, 99-111. https://doi.org/10.1016/j. engstruct.2014.07.001

32. Smyrou, E.; Blandon, C.; Antoniou, S.; Pinho, R.; Crisafulli, F. (2011) Implementation and verification of a masonry panel model for nonlinear dynamic analysis of infilled RC frames. Bull. Earthquake Engin., 9 (5), 1519-1534. https:// doi.org/10.1007/s10518-011-9262-6

33. EN 1998-6 (2005): Eurocode 8: Design of structures for earthquake resistance.

34. EN 1996-1-1 (2005) Eurocode 6: Design of masonry structures.

35. Mostafaei, H.; Vecchio, F.J.; Kabeyasawa, T. (2008) Nonlinear displacement-based response prediction of reinforced concrete columns. Eng. Struct., 30(9), 2436-2447. https://doi.org/10.1016/j.engstruct.2008.01.020

36. RENADIC. University of Chile. Faculty of physics sciences and mathematics (Spanish) Available at: http://www. renadic.cl/ (July 2015).

37. Manfredi, G. (2001) Evaluation of seismic energy demand. Earthqua. Eng. Struct. Dyn., 30 (4), 485-499. https://doi. org/10.1002/eqe. 17

38. Arias, A. (1969) Measure of earthquake intensity pp. $438-483$.
39. ASTM C62 - 10. Standard Specification for Building Brick (Solid Masonry Units Made From Clay or Shale)

40. Demir I. (2008) Effect of organic residues addition on the technological properties of clay bricks. Waste Manage., 28, 622-627. https://doi.org/10.1016/j.wasman.2007.03.019

41. Eliche-Quesada, D.; Corpas-Iglesias, F.A.; Pérez-Villarejo, L.; Iglesias-Godino, F.J. (2012) Recycling of sawdust, spent earth from oil filtration, compost and marble residues for brick manufacturing. Construcc. Build. Mat., 34, 275-284. https://doi.org/10.1016/j.conbuildmat.2012.02.079

42. Barbieri L.; Andreola F.; Lancellotti I.; Taurino R. (2013). Management of agricultural biomass wastes: Preliminary study on characterization and valorisation in clay matrix bricks. Waste Manage., 33, 2307-2315. https://doi. org/10.1016/j.wasman.2013.03.014

43. Bánhidi, V.; Gömze, L.A. (2008) Improvement of insulation properties of conventional brick products. Mater. Sci. Forum, 589, 1-6. https://doi.org/10.4028/www.scientific.net/MSF.589.1

44. Elinwa, A.U. (2006) Effect of addition of sawdust ash to clay bricks. Civ. Eng. Environ. Syst., 23(4), 263-270. https:// doi.org/10.1080/10286600600763149

45. Maciá, M. E.; Rolando A. (2013) Young modulus variation of a brickwork masonry element submitted to high temperatures. Mater. Constr., 63(309), 105-116. https://doi. org/10.3989/mc.2012.02311

46. Paulay T.; Priestley M.J.N. (1992) Seismic Design of Reinforced Concrete and Masonry Buildings. Jhon Wiley\&Sons, Inc. New York (1192) ISBN 978-0-471-54915-4.

47. Goel, R.K.; Chopra, A.K. (1998) Period formulas for concrete shear wall buildings. J. Struct. Eng-ASCE, 124 (4), $426-433$. 